Ks. Tomasz Tułodziecki

UMK, Toruń

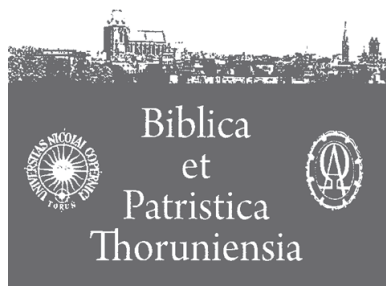

$2(2009)$

\title{
Jonasz wobec pogan
}

Księga Jonasza stanowi integralną część zbioru 12 proroków mniejszych ST, jakkolwiek w wielu szczegółach różni się znacząco od pozostałych dzieł tej części Biblii. Najważniejszą różnicą jest forma literacka Księgi. Dominuje w niej klasyczna narracja w 3 osobie liczby pojedynczej, z wyjątkiem poetyckiego fragmentu Jon 2,1-11, który, podobnie jak inne utwory prorockie, jest ubrany w poetycką szatę wyszukanych paralelizmów i innych figur retorycznych. Jednak spośród wypowiedzi czysto prorockich wygłoszonych przez Jonasza znana jest właściwie tylko jedna: „Jeszcze czterdzieści dni i Niniwa zostanie zniszczona” (Jon 3,4).

Ciekawym i całkowicie oryginalnym aspektem Księgi Jonasza jest osoba głównego bohatera. Właściwie można ją określić jako „antyproroka”. Żaden inny prorok ST nie opierał się tak konsekwentnie Bożemu powołaniu jak Jonasz. Potwierdza to kilka faktów zawartych w Księdze: podróż do Tarszisz, czyli w kierunku przeciwnym do tego, który wskazał Jahwe; jeden zamiast trzech dni głoszenia Słowa Bożego w Niniwie; przepowiadanie zniszczenia asyryjskiej stolicy zamiast głoszenia miłosierdzia Jahwe; gniew zamiast radości z nawrócenia pogańskiego miasta (Jon 4,1). Niewątpliwie zatem Jonasz jest bardzo osobliwym prorokiem, który dodatkowo w żadnym fragmencie Księgi nie jest nazywany bezpośrednio tym tytułem i przypisano go Jonaszowi tylko ze względu na formę powołania i sposób przekazu orędzia Bożego.

Księga dzieli się w swojej strukturze na dwie zasadnicze części (Jon 1,4-16; 3,1-4,4), które odznaczają się zamierzonym paralelizmem poszczególnych elementów literackich. W obu fragmentach chodzi o ratunek w niebezpieczeństwie śmierci i główne miejsce zajmuje w nich grupa pogan. Na czele tych grup stoi bardzo konkretny przywódca: kapitan okrętu i król Niniwy. Członkowie tych zbiorowości zachowują się wzorcowo, a ich postawa kończy się albo oddaniem chwały Jahwe (marynarze na okręcie), albo nawróceniem (mieszkańcy Niniwy).

Jak zauważamy, paralelne elementy literackie dotyczą postawy pogańskich bohaterów Księgi Jonasza. Kryje się w nich pewna sympatia dla ich zachowań. Wyjątkiem w pozytywnym patrzeniu na ich działanie $\mathrm{w}$ historii Jonasza jest krótki fragment psalmu, jaki wypowiada Jonasz we wnętrznościach ryby. Chodzi tu o tekst Jon 2,9: „Czciciele próżnych marności opuszczają Łaskawego dla nich”. Wiadomo jednak, że tekst tego psalmu stanowi specyficzny dodatek do głównej 
części tekstu Księgi Jonasza pisanej prozą. Zawiera on zdecydowanie inną perspektywę teologiczną, którą narzuca czas i środowisko powstania tego tekstu ${ }^{1}$.

Relacja Izraelitów (lepiej Izraelity) do pogan oraz autora tekstu do członków narodu wybranego i „nie-Izraelitów” nie ma sobie podobnych w ST. Poganie odznaczają się Bożą bojaźnią, są gotowi do nawrócenia, cytują słowa Jahwe i sprawują żydowskie obrzędy liturgiczne (1.10.14). Ponadto ogłaszają edykt oparty na słowach izraelskiego proroka $(3,8-9)$ i oddają się całkowicie dziełom pokutnym $(3,5)$. Warto postawić pytanie o przyczynę tak wyjątkowego nastawienia autora Księgi Jonasza do tych, którymi najczęściej pogardzano i zakazywano wspólnoty z synami obietnicy i przymierza z Jahwe. Wydaje się, że świadomie prowokuje on adresatów swego utworu do stawiania sobie trudnych pytań dotyczących relacji Izraelitów z poganami, np.: czy zasięg Bożego Miłosierdzia ogranicza się, czy też powinien ograniczać się tylko do synów Jakuba? Czy to właśnie z powodu zasięgu misji bohater Księgi odmawia realizacji swego powołania pośród pogan? Czy Boże Miłosierdzie ma rzeczywiście charakter uniwersalny, rozciągając się zarówno nad całymi narodami, poszczególnymi ludźmi, jak i nad zwierzętami? Na te i inne pytania, jakie stawia lektura Księgi Jonasza w kwestii roli i postawy pogan w Bożym planie zbawienia, spróbujemy odpowiedzieć w niniejszym artykule.

\section{Tradycyjny obraz pogan w Księdze Jonasza (Jon 1,4-5)}

Pierwsza informacja, jakiej dostarcza nam autor Księgi Jonasza na temat pogan, pojawia się w Jon 1,4-5. Jej treść wpisuje się w dość rozpowszechniony obraz ludów niewierzących w Jahwe na kartach ST. Burza na morzu zmusza marynarzy do bardzo drastycznych kroków, zarówno na poziomie fizycznym: pozbycie się ładunku i całego zbędnego balastu, jak i na poziomie duchowym: desperacka modlitwa do osobistych bóstw. Instrumentem wywołującym strach i przerażenie marynarzy jest przeciwny wiatr, który wprowadza na scenę potężną nawałnicę. W tekstach biblijnych jest to częsty element natury, który kontrolowany przez Boga, kierowany jest przeciwko poganom, przeciwnikom Izraela. Najbardziej wymownym przykładem jest tradycja związana $z$ wyjściem narodu wybranego z Egiptu, gdzie gwałtowny wiatr wschodni spowodował wodną nawałę, która powstrzymała i zatopiła rydwany faraona (Wj 14,21-28; Pwt 7) ${ }^{2}$. Gwałtowny wicher połączony z burzą czy wodną nawałnicą jest też często narzędziem Bożego Sądu (Jr 23,19; 25,32; 30,23; Am 1,14; Ps 83,16). Poza tym zwrot „wielka burza” (sa'ar

1 Por. E. Zenger, Das Zwölfprophetenbuch, w: E. Zenger u. a, Einleitung in das Alte Testament, Stuttgart 199833, 501; J.A. Soggin, Introduzione all'Antico Testamento (Brescia 19874, s. 442.

2 Por. L. Alonso Schökel, J.L. Sicre Diaz, I Profeti, Roma 1996, s. 1156. 
gādôl) odnajdujemy poza tekstem Jon 1,4 tylko w Jr 25,32. Może to wskazywać, że autor Księgi Jonasza skorzystał z tradycji jeremiaszowej w kompozycji swojej narracji.

Szczególnie owa duchowa reakcja marynarzy, których w dalszych fragmentach autor nazywa po prostu mężami, wydaje się godna bliższej uwagi. W obliczu żywiołu, który atakuje okręt, marynarze nie tylko trudzą się nad utrzymaniem statku na falach, lecz także zanoszą modlitwy do swoich bogów. Tradycyjnie tego typu modlitwa nie odnosi skutku na kartach ST. Przykładem podobnej modlitwy, która nie jest i nie może być wysłuchana, jest opowiadanie o Eliaszu walczącym z fałszywymi prorokami Baala. Ich wezwania, tańce i okaleczenia nie odnoszą pożądanego skutku (1 Krl 18,20-40)3. Podobny wymiar modlitwy podaje opis pobytu Arki Przymierza w kraju Filistynów (1 Sm 4-5). Zwłaszcza tekst 1 Sm 5 podaje ogrom zniszczeń (mordercze plagi, podobne do egipskich), jakie wywołuje Arka. Filistyni dotknięci plagą guzów postanawiają ją usunąć. Wielu dotkniętych przez Boga i umierających wznosiło błagalne modły (dokładnie šawāh - okrzyk błagania podobnie jak w 2 Sm 22,7 i Ps 18,7) lecz te, podobnie jak w przypadku pogańskich marynarzy i proroków Baala, pozostają bez odzewu (1 Sm 5,12). Zatem tekst Jon 1,4-5 wpisuje się w ogólną zasadę przyjętą w tradycjach ST, która podkreśla nieskuteczność modlitwy zanoszonej przez pogan.

Należy zaznaczyć, że w przeciwieństwie do modlących się pogan modlitwa Izraelitów zazwyczaj odnosi skutek. Potwierdzają to liczne przykłady (Jr 8,19; Lm 3,56; Ps 36,16; 39,13; 40,2; 102,2; 145,19), z których najbardziej wymowny wydaje się tekst mówiący o modlitwie uciskanych Izraelitów w Egipcie: „Izraelici narzekali na swoją ciężką pracę i jęczeli, a narzekanie na ciężką pracę dochodziło do Boga" (Wj 2,23). W tekście Jon 1,5-6 Jonasz ma okazję wywołać odpowiednią reakcję Boga. Jak sugeruje autor Księgi, w przeciwieństwie do pogańskich marynarzy, jako Izraelita ma szansę wyprosić ratunek u Jahwe. Jednak w całym tekście Księgi Jonasza nie odnajdziemy żadnego fragmentu, który potwierdzałby modlitwę proroka w czyjejś intencji. Co najwyżej modli się we własnej (Jon 2,2; 4,2). Warto również zauważyć, że to nie modlitwa prowadzi ostatecznie do rozwiązania dramatu. Ratunek, jak wynika z Księgi, przychodzi przez konkretny czyn (wyrzucenie Jonasza za burtę). Zatem pierwszy obraz, w którym bohaterami w Księdze Jonasza są poganie, nie odbiega od utartej tradycji. Nie mogą być partnerami Boga Jahwe. Ich słowa i czyny wobec Niego są bezskuteczne. Odmianę ich sytuacji powoduje nawrócenie i wyznanie wiary marynarzy, które następuje w ostatnich wierszach pierwszego rozdziału Księgi (Jon 1,16).

3 Por. U. Struppe, Bie Bücher Obadja, Jona, NSK 24/1; Stuttgart 1996, s. 129-130; por. M.A. De La Torre, Liberating Jonah. Forming an Ethics of Reconciliation, New York 2007, s. 22. 


\section{Pozytywny obraz pogan a historyczność Księgi Jonasza}

Od dawna toczy się dyskusja nad świadectwami mogącymi pomóc w ustaleniu prawdopodobnej daty powstania Księgi Jonasza. Argumentem za dość późną redakcją Księgi jest język użyty w tekście. Hebraizmy i arameizmy mieszają się ze sobą. Wiele z nich wyraźnie wskazuje na epokę historyczną, z której zostały zaczerpnięte. Chodzi tu czasy po niewoli babilońskiej, czyli lata po roku 538 przed Chr. Świadectw tego typu w tekście Księgi Jonasza z racji bardzo niewielkiej objętości samego dzieła nie ma zbyt wiele, warto jednak przytoczyć niektóre z nich.

Pierwszym przykładem jest użycie wielkich liczb, np. 120000 tys., w tekście Jon 4,11. Podobne wyrażenia charakteryzują tradycje zawarte w księgach Daniela, Ezdrasza i Nehemiasza oraz w Księgach Kronik. Na pochodzenie z podobnych tradycji wskazuje również zwrot „Bóg nieba” użyty w tekście 1,9. Z takim terminem spotykamy się także w stosunkowo późnych dziełach historyczno-dydaktyczych ST: Tobiasza i Judyty (np. Tb 7,13; 8,15; Jdt 5,8; 11,17). Stwierdzenie, iż cały naród „od największego do najmniejszego" podjął dzieło pokutne, odnajdujemy tylko w późnych tradycjach literackich ST, np. Est 1,5.20; 2 Krn 34,30.

Należy zauważyć również, że autor Księgi Jonasza jest doskonałym znawcą literatury ST. Uwidacznia tę znajomość poprzez stosowanie cytatów wyjętych wprost $\mathrm{z}$ innych ksiąg ST. W dwóch fragmentach (Jon 3,9-10; 4,2) dostrzegamy nawiązania do Księgi Joela 2,13-14. We fragmencie Jon 3,8-10 odnajdujemy również wyraźne odniesienia do tradycji związanej z prorokiem Eliaszem (1 Krl 17 i 19), zwłaszcza do tekstów w $1 \mathrm{Krl}$ 19,4.9. W opisie dotyczącym nawrócenia króla Niniwy możemy odnaleźć nawiązania do postawy króla Jojakima opisanej przez proroka Jeremiasza 36. Jest to podobieństwo na zasadzie kontrastu. Wiemy bowiem $\mathrm{z}$ historii, że król Jojakim nie podjął wezwania do nawrócenia tak jak anonimowy król Niniwy w Jon 3. Na zasadzie kontrastu, tym razem z Mojżeszem, został przedstawiony również sam Jonasz. Odnajdujemy tu analogię z Księgą Wyjścia 32-34, która ukazuje Mojżesza skarżącego się na postawę Izraelitów, ale w przeciwieństwie do Jonasza, umiejącego także błagać Boga w ich imieniu o przebaczenie ${ }^{4}$.

Znajomość i zastosowanie dawnych tradycji w dziele Jonasza ma przede wszystkim bardzo ważne znaczenie teologiczne. Rozwija ono bowiem, zapoczątkowaną już w tradycji deuteronomicznej, tzw. teologię nawrócenia. Stworzyła ona zasadę, według której Izraelowi, który się nawraca, Bóg pragnie na nowo przebaczyć wszystkie grzechy i nieprawości. Widać to zwłaszcza w historii Południowej Monarchii, gdzie początkowy zamiar unicestwienia narodu za panowania Manassesa ( $2 \mathrm{Krl} 21,10-15)$ zostaje zmieniony na karę wygnania.

4 Por. J.A. Soggin, dz. cyt., s. 442-443. 
Szczególne znaczenie dla owej teologii nawrócenia mają słowa Mojżesza w Pwt. Zwiastują one nie tylko odrzucenie i wygnanie Izraela, ale ukazują one naród także w perspektywie pokuty i powrotu do Jahwe (Pwt 4,23-31) .

W opowiadaniu o Jonaszu perspektywa nawrócenia przybiera rewolucyjne, jak na swoją epokę, rozmiary i zasięg. Obejmuje ona również symbol bezbożności i prześladowań, asyryjską Niniwę. Ta odważna koncepcja autora Księgi Jonasza o włączeniu pogan w Bożą logikę miłosierdzia nie była z pewnością jeszcze zbyt rozpowszechniona w czasach powstawania dzieła. Dlatego też autor musiał uciec się do szczególnej formy literackiej (midrasz haggadyczny), aby wyrazić swoje przekonanie o powszechności przebaczenia ${ }^{6}$.

$\mathrm{Z}$ literackiego punktu widzenia, a także na podstawie przesłanek wynikających z treści Księgi Jonasza można przyjąć, że dzieło to powstało pod koniec IV wieku przed Chr. Widać w nim dość wyraźne nawiązania do Księgi Hioba. Dotyczy to zwłaszcza ram geograficznych obu tekstów. Akcja obydwu ksiąg rozgrywa się na terenach pogańskich: w Księdze Jonasza jest to pogański okręt i pogańskie miasto Niniwa, w Księdze Hioba jest to miasto Uz w Arabii. Stąd bierze się uniwersalny charakter obu tych dzieł.

Nieco inne przesłanie teologiczne odkrywa jedyny poetycki fragment Księgi Jonasza: psalm w Jon 2,1-11. Perspektywa nawrócenia pogan w tym utworze została osłabiona. Jego autor stawia pod znakiem zapytania pobożność i ich gotowość do nawrócenia przez fakt stałej łączności z kultem bożków (Jon 2,9). Większość komentatorów jest dziś zgodna, że tekst psalmu Jon 2,1-11 został dołączony znacznie później do zasadniczego tekstu narracyjnego Księgi Jonasza? Zabieg literacki redaktora, który włączył psalm Jon 2,1-11 do całości dzieła, miał na celu wyhamowanie tendencji powszechnego i pochopnego włączania pogan do wspólnoty wybranych przez Jahwe. Reguła, która wynika z lektury Jon 2,1-11, jest prosta: tylko tym, którzy czczą Boga Jahwe (co wcale nie wynika z postawy mieszkańców Niniwy), gwarantuje on ratunek i wybawienie.

5 Por. G. Braulik, Die Theorien über das Deuteronomistische Geschichtswerk, w: E. Zenger u. a, dz. cyt., s. 189-190.

6 Por. M.A. De La Torre, dz. cyt., s. 11-12; J. Synowiec, Prorocy Izraela. Ich Pisma i Nauka, Kraków 1999³, s. 455; T. Brzegowy, Prorocki Wymiar Księgi Jonasza, AK 85 (1993), s. 11.

7 Szczegółów, które świadczą o późniejszym dołączeniem tekstu Jon 2,1-11, jest kilka, np.: a) sytuacja zaznaczona w psalmie nie odpowiada tej w narracji, tzn. hymn jest dziękczynieniem za uwolnienie, podczas gdy Jonasz był jeszcze we wnętrzu ryby, czyli w stanie niewoli; 2) język psalmu jest inny od pozostałych fragmentów dzieła, np. nie ma w nim żadnego arameizmu, brak w psalmie ulubionego terminu autora Księgi Jonasza „wielki” - gādôl, a język psalmu ma charakter liturgiczno-kultyczny, którego brak w narracji; 3) zachowanie samego Jonasza w psalmie, które nacechowane jest dziękczynieniem i posłuszeństwem, odbiega znacząco od tego po opuszczeniu ryby, które zdominowane jest przez niezadowolenie i nieposłuszeństwo. Por. L. Alonso Schökel, J.L. Sicre Diaz, dz. cyt., s. 1148. 
Omawiając przesłanki historyczne wzmacniające pozytywny obraz pogan w Księdze Jonasza, warto zwrócić uwagę na symbol stolicy asyryjskiego państwa Niniwy. Miasto to było notowane już w czasach prehistorycznych i za panowania Hammurabiego należało do najważniejszych miast mezopotamskich. Jednak dopiero za czasów Senaheryba I (704-681) Niniwa stała się stolicą państwa asyryjskiego (2 Krl 19,36; Iz 37,37). Za jego panowania miasto zostało znacząco rozbudowane i upiększone. Umieszczono w nim m.in. słynną bibliotekę. Upadek miasta nastąpił w roku 612 po najeździe Medów i Persów.

Dla samych Izraelitów Niniwa była miastem - symbolem wszelkiego zła i grzechu. Po przeprowadzeniu kilku wypraw wojennych na teren północnej monarchii Asyryjczycy doprowadzili ostatecznie do upadku państwa izraelskiego w roku 721 przed Chr. Wielu mieszkańców zostało przesiedlonych do Asyrii. Również południowe Państwo Judy ze stolicą w Jerozolimie doświadczyło panowania Asyrii, gdy w roku 701 stało się lennikiem Niniwy. Co prawda, z niewiadomych przyczyn król asyryjski odstąpił od bram Jerozolimy. To wydarzenie stało się podłożem mitów i legend o niezwyciężoności Jerozolimy i szczególnego błogosławieństwa Bożego dla miasta. Asyryjczycy odgrywali w historii Izraela bardzo szczególną rolę odwiecznego i niepokonanego wroga. Podobne doświadczenia w kontaktach z Asyryjczykami zbierały prawie wszystkie mniejsze państwa starożytnego Wschodu w VIII i VII wieku przed Chr. Teksty ST wielokrotnie informują nas o dokonaniach Asyrii i o zagrożeniu, jakim było to państwo dla Izraela i innych narodów. Dziełem wyróżniającym się w tym temacie jest Księga proroka Nahuma (Na 1-3), która praktycznie w całości jest poświęcona wojnom z Asyrią i zbrodniami, jakie były związane z jej najazdem. To właśnie prorok Nahum określa Niniwę jako „miasto krwawe” (Na 3,1). Księga Rodzaju dodaje w 10,10-11, że jej budowniczym był legendarny Nimrod ${ }^{8}$.

Wcześniejsze obserwacje pozwalają nam stwierdzić, że w czasach redagowania Księgi Jonasza miasto Niniwa już nie istniało. Zresztą autor Księgi nigdzie wprost nie nazywa jej stolicą asyryjskiego imperium. Dlatego też umieszczenie akcji w drugiej części Księgi Jonasza właśnie w Niniwie ma znaczenie symboliczne. Niniwa jest w tekście Jon 3-4 wielką, odległą metropolią przemocy i zła. Ale właśnie na przykładzie tego skumulowanego zła Księga Jonasza ukazuje moc Bożego Miłosierdzia, dla którego nie ma barier, granic i krat. Mieszkańcy Niniwy $\mathrm{i}$ ich gotowość do nawrócenia tworzą wymowny kontrast $\mathrm{z}$ egoistyczną postawą proroka Jonasza. 


\section{Nawrócenie pogan i nawrócenie Boga}

Motywem przewodnim Księgi Jonasza jest termin „nawrócić się” (šûb). Częstotliwość jego występowania nasila się w trzecim rozdziale dzieła. We fragmencie Jon 3,8-9 nawrócenie pozostaje w sferze życzeń i pragnień, które realizują się w tekście Jon 3,10: „Zobaczył Bóg czyny ich, że odwrócili się od swojego złego postępowania. I ulitował się Bóg nad niedolą, którą postanowił na nich sprowadzić, i nie zesłał jej”. Tylko w tym fragmencie, w całym ST, termin „nawracać się" jest zastosowany w celu przedstawienia postawy ludzi, którzy naprawdę się nawrócili. W innych przypadkach czasownik ten wyraża najczęściej skargę na tych, którzy się nie nawrócili (np. Iz 6,10; Jr 3,10; 5,3; 8,5; Oz 11,5), warunek sformułowany zawsze w podobny sposób: jeśli się nie nawrócą... (np. 1 Krn 8,48; 2 Krn 6,38; Ne 1,9) lub rozkaz: nawróćcie się (np. Jr 35,15; 36,3.7). Jednak tylko o mieszkańcach asyryjskiej Niniwy mówi się, iż rzeczywiście się nawrócili9.

Nadzieja króla, o którym mowa w Jon 3,9, wypełnia się w stwierdzeniu: „I ulitował się Bóg nad niedolą, którą postanowił na nich sprowadzić...”. Podobne sformułowanie pojawia się również $\mathrm{w}$ dwóch innych ważnych tekstach ST: w Jr 26,13.19 oraz w Wj 32,14. Szczególnie istotny jest fragment z Księgi Wyjścia, gdyż brzmi on dosłownie tak samo jak Jon 3,10. Prawdopodobnie autor Księgi Jonasza zacytował ten fragment Pięcioksięgu w swoim dziele prorockim. W Księdze Wyjścia 32,12-14 obok informacji o nawróceniu i litości Pana Boga znajdują się wzmianki o palącym Bożym gniewie. Ów gniew jest skierowany przeciw Izraelitom, którzy tańczą wokół złotego cielca. Mojżesz już w czasie tego bałwochwalczego tańca zanosi prośby do Pana i Bóg lituje się nad narodem wybranym. Ludzie z Niniwy w przeciwieństwie do Izraelitów nawracają się i porzucają drogę swojej nikczemności i złych czynów. Możemy zatem przyjąć, że Niniwici są bardziej skorzy do nawrócenia aniżeli członkowie narodu wybranego. Poza tym warto zaznaczyć, iż w tekście Jon 3 to król Niniwy, w miejsce Mojżesza, nawołuje do nawrócenia, zamiast Izraelity Jonasza, który nie chce mówić ani o wierze $\mathrm{w}$ Jahwe, ani o nawróceniu ${ }^{10}$.

Teksty Jr 26,13.19 i Wj 32,12-14 teologicznie najbardziej zbliżają się do idei zawartych w Jon 3,8-10, jednak również wiele innych fragmentów ST, z małymi różnicami, upodabnia się do tekstów Księgi Jonasza. Zwłaszcza edykt króla Niniwy bardzo mocno nawiązuje do klasycznych mów prorockich.

Wypada się zapytać, co pobudza w Księdze Jonasza samego Boga do zmiany planów, rzec by można - do nawrócenia. Odpowiedź autora Księgi Jonasza jest jasna: Bóg „nawraca się”, odwraca swój wyrok, widząc, że mieszkańcy Niniwy odwrócili się od swego złego postępowania. Teksty ST dotyczące nawrócenia

9 Por. H.-J. Fabry, šûb, TDOT XIV, s. 508-509.

10 Por. A.J. Hauser, Jonah: in Pursuit of the Dove, JBL 104 (1985), s. 31. 
zwracają uwagę na jeden ważny aspekt: mówią wyraźnie, iż podczas nawrócenia ważniejsze są czyny aniżeli słowa: „Gdy wyciągniecie ręce, odwrócę od was me oczy. Choćbyście nawet mnożyli modlitwy, Ja nie wysłucham. Ręce wasze pełne są krwi. Obmyjcie się, czyści bądźcie! Usuńcie zło uczynków waszych sprzed moich oczu! Przestańcie czynić zło!” (Iz 1,15-16; por. także Am 5,14-15). Dlatego też w Księdze Jonasza autor podkreśla, że Bóg zlitował się nad Niniwą, gdyż widział ich czyny, natomiast nic nie mówi o tym, jakoby wysłuchiwał ich modlitw. Podobnie widzi ten problem Miszna, pytając, jaki powinien być porządek postu, udziela jasnej odpowiedzi: „Moi bracia, nie powiedziano czasem o mieszkańcach Niniwy: i widział Bóg jak ich pokutny wór i ich posty? Nie! Lecz mówi: Bóg widział ich czyny, że się odwrócili od swej złej drogi!” (Miszna, Ta’anit 2,1). Z zachowaniem Niniwitów koresponduje więc zachowanie samego Boga: Ponieważ mieszkańcy Niniwy nawrócili się od swoich złych czynów, także Bóg odwrócit od nich swój gniew (dosłownie: ulitował się nad niedolą, którą chciał sprowadzić i nie zesłał jej).

Czy zatem Bóg może się nawrócić, czynić pokutę, czy też odczuwać żal i skruchę? Sformułowanie to może wydawać się obce i dziwne. Jednak dla autorów ST, zwłaszcza dla proroków, mówienie o żalu, litości i nawróceniu się Boga jest bardzo powszechne. Zwrot „Bóg się zlitował” czy też „Boża litość” w sensie pozytywnym występuje 30 razy w ST. Poza tym liczne teksty starotestamentalne mówią również o tym, że Jahwe nie może się zlitować, wskazując na niemożność cofnięcia i odwołania niektórych wyroków i postanowień (Lb 23,19; 1 Sm 15,29). Doświadczenie Bożej litości w historii Izraela uwidacznia się szczególnie w chwilach obwieszczenia Bożego sądu. Właśnie w obliczu takich chwil prorocy podkreślają prawdę, iż Bóg Izraela jest Bogiem praktykującym litość i miłosierdzie (Oz 11,9). Tajemnice litości Boga i zaniechania wykonania wyroku wobec narodu wybranego prorok Ozeasz tłumaczy wewnętrzną walką Jahwe, która jest ostatnim sposobem ratunku dla Izraela wobec wielkich win i nieodwołalnego wyroku $(\mathrm{Oz} 11,8)$. Bóg czyni tak, gdyż pamięta o pierwszych chwilach istnienia narodu wybranego (Oz 11,1.9; Am 7,2.5) i o obietnicach, jakie złożył przodkom (Wj 32,11-14). Po niewoli babilońskiej znaczenie wyrażenia „litość Boga” zmieniło się. Zapanowało przekonanie, iż prowokuje ją ludzkie zachowanie. Od tej chwili hebrajski termin rāḥam oznacza bardziej „współczucie” (Pwt 32,36; Sdz 2,18; Ps 90,13; 106,45), „miłosierdzie”, „łaskę” lub „przebaczenie” (Ps 78,38; 85,2-3) ${ }^{11}$.

Nawrócenie pogan i nawrócenie Boga jest więc zasadniczym tematem Jon 3. Jednak termin nawracać się (šûb) spotykamy już w rozdziale pierwszym Księgi Jonasza (Jon 1,13): Ludzie ci starali się, wiosłując, zawrócić ku lądowi... Należy

11 Por. J. Jeremias, Die Reue Gottes. Aspekte alttestamentlichen Gottesvorstellung, BS 65, Neukirchen-Vluyn 1975. 
zapytać się o symboliczny wydźwięk tych słów: Kogo lub co chcieli zawrócić albo nawrócić mężowie na okręcie, wiosłując ku lądowi. Być może zadaniem lektora tekstu Księgi Jonasza w oczach autora jest dodanie imienia krnąbrnego proroka, np. Ludzie ci starali się, wiosłując, zawrócić ku lądowi, aby nakazać Jonaszowi zawrócenie z błędnej drogi. Ich wysiłek jest jednak daremny i wszystkie fakty w Księdze Jonasza zwiastują ich rychłą zagładę. Tym samym autor wskazuje na ważną prawdę, iż nikt nie może wyręczyć bliźniego w jego osobistym nawróceniu. Także marynarze nie mogą się nawrócić w miejsce Jonasza. Nawrócenie jest osobistym i indywidualnym darem Jahwe i odbywa się także na płaszczyźnie indywidualnej.

Swój kulminacyjny punkt opowiadanie o proroku Jonaszu osiąga we fragmencie Jon 4,2-3. Jest to zarazem opis największego kryzysu samego proroka podczas realizacji dzieła zleconego mu przez Jahwe. Ponownie, podobnie jak we wnętrznościach ryby, modli się do Jahwe. Gdy sytuacja dotyczy skarżenia się na coś lub na kogoś bądź oskarżania innych, modlitwa przychodzi Jonaszowi $\mathrm{z}$ łatwością. W pozostałych sytuacjach jest on bardzo oszczędny w słowach. Miastu Niniwie poświęcił tylko 5 słów swojej nauki, marynarzom 16, natomiast jego skarga i żal, kierowane do Boga, w obliczu nawrócenia Niniwitów zawierają aż 38 słów $^{12}$.

Jego zgorzknienie wynika $\mathrm{z}$ faktu, który jako Izraelita powinien dobrze znać. Jonasz boi się, że jego działalność może rzeczywiście okazać się skuteczna, gdyż wie, iż Bóg, którego wyznaje i któremu służy, „jest Bogiem łagodnym i miłosiernym, cierpliwym i pełnym łaskawości, litującym się nad niedolą" (Jon 4,2). Już w konfrontacji z marynarzami (Jon 1,9) przyznaje, iż zna takiego Boga. W wierszu Jon 4,2 widać wyraźne nawiązanie do tekstu Jl 2,13: „Rozdzierajcie jednak serca wasze, a nie szaty! Nawróćcie się do Pana Boga waszego! On bowiem jest łaskawy, miłosierny, nieskory do gniewu i wielki w łaskawości, a lituje się na widok niedoli”. Temat ten obecny jest także w wielu innych tekstach ST: Wj 34,6; Ne 9,17; Ps 86,15; 103,8; 145,8 (por. także: Ne 9,31; Ps 111,4; 112,4) ${ }^{13}$. Prorok Jonasz uciekał z miasta, ponieważ obawiał się o miłosierdzie i dobroć Boga względem Niniwy. Stolica Asyrii była „krwawym miastem”, miastem przestępstwa i przemocy i była dumna $\mathrm{z}$ tego faktu (Na 3,1). Izrael, w przeciwieństwie do pogan, już w bardzo dawnych tradycjach był ukierunkowany na fundamentalną sprawiedliwość. Potwierdza to jeden $\mathrm{z}$ najstarszych tekstów prawnych zawartych w Wj 34,10-17. W kontekście tego fragmentu znajdujemy opis teofanii (Wj 34,6), do której nawiązuje prorok: „Tyś jest Bóg łagodny i miłosierny, cierpliwy i pełen łaskawości, litujący się nad niedolą". (Jon 4,2).

12 Por. U. Struppe, dz. cyt., Jona, s. 128.

13 Por. H. Simian-Yofre, U. Dahmen, rāḥam, TDOT XIII, s. 450. 
Jonasz oponuje przeciwko temu stanowisku. W jego postawie daje się zauważyć wielki kontrast: To, co było dla Mojżesza i Izraelitów fundamentem nadziei, jest dla proroka podstawą gniewu i zwątpienia. Krótko mówiąc, Jonasz nie chce znać Boga, o którym mowa w Wj 34,6 i Jl 2,13, i obstaje przy swojej prawdzie: grzech i nieprawość muszą być surowo ukarane. $Z$ jednej strony zatem teologia Księgi Jonasza wpisuje się w dawną tradycję ST, z drugiej zaś wykracza poza nią. W Księdze Joela 2,13 nadzieja jest pokładana w Bogu dobrym i miłosiernym, jednak dary skierowane są tylko do Izraela. Księga Jonasza rozszerza tę perspektywę. Miłosierdzie Jahwe dotyczy wszystkich ludzi, zarówno wtedy, gdy nie są oni członkami narodu wybranego, jak i w przypadku tych, którzy Jahwe w ogóle nie znają. Tak wynika z samego tekstu Księgi Jonasza: Ludzie z Niniwy uwierzyli i czynili pokutę, wcale nie wierząc Jahwe, a jedynie Bogu (Jon 3,5). Zatem niekonieczna jest wiara w Jahwe, gdy Bóg pragnie okazać swoje miłosierdzie i łaskę.

\section{Próba podsumowania}

Wyjątkowość Księgi Jonasza polega na tym, że całość akcji tego opowiadania rozgrywa się pośród pogan, tzn. nie-Izraelitów. Jest to myśl rewolucyjna. Dotychczasowe tradycje literackie Biblii wskazują na niektóre postaci spoza wspólnoty narodu wybranego, które dostąpiły udziału w tej samej obietnicy zbawienia (Rahab, Rut, Uriasz Hetyta, Naaman Syryjczyk, Wdowa z Sarepty Syjońskiej), jednak nigdzie, nawet w Księdze Rut, ich rola nie jest tak dominująca jak w Księdze Jonasza ${ }^{14}$. Wraz z nimi dokonuje się na kartach Księgi cud nawrócenia, którego próżno szukać w Jerozolimie pośród królów Judy. W porównaniu z nimi król Niniwy może służyć jako wzór otwarcia na przepowiadanie prorockie. Jonasz na tle niewierzących w Jahwe jawi się jako karykatura proroka, który zna dawne prawdy o Bożym Miłosierdziu, uznaje w nim Pana i Stwórcę (Jon 1,9), lecz w żaden sposób nie potrafi wyciągnąć $\mathrm{z}$ tego faktu odpowiednich konsekwencji.

Znaczenie całej narracji w Księdze Jonasza jest skierowane przeciwko wszelkim nacjonalistycznym i partykularnym zapędom. Autor tego tekstu jest przekonany, że zbawienie i dobrobyt Izraela wcale nie są najważniejszymi ideami w Bożych planach. Ta prawda znalazła swoje pogłębienie w niektórych midraszach i nauczaniu rabinackim. Jednak dopiero pisma NT i ich chrześcijańska interpretacja uczyniły z Niniwy wzór nawrócenia stawiany współczesnym Chrystusowi (Mt 12,41; Łk 11,29-32). W swoim kontekście historycznym Księga Jonasza próbuje polemizować z bardzo nacjonalistycznym punktem widzenia dziejów zbawienia, jaki zapanował po powrocie z niewoli babilońskiej. Chodziło

14 Por. T. Brzegowy, Bóg pragnie zbawić wszystkich ludzi. Religijne przesłanie Księgi Jonasza, AK 84 (1992), s. 211. 
zwłaszcza o bardzo drastyczne ograniczenie kontaktów z obcokrajowcami za czasów Nehemiasza, zwłaszcza o zakaz małżeństw mieszanych (Ne 13,3-29), który prowadził do izolacji i poważnych zadrażnień z innymi narodami. Słynny stał się konflikt z Samarytanami, który spowodował poważną schizmę. Z relacji biblijnych wynika, że spór powstały podczas odbudowy murów jerozolimskich pomiędzy Sanballatem a Nehemiaszem był tylko preludium do dalszych zadrażnień między tymi stronami. Kolejny konflikt, który możemy określić mianem żydowsko-samarytańskiego, wspomina Księga Nehemiasza 13,28. Z tekstu wynika, że syn najwyższego kapłana Jojady ożenił się z córką Sanballata i został usunięty ze społeczności żydowskiej. Czyn Nehemiasza miał w tym przypadku również polityczne podłoże, gdyż przeszkodził namiestnikowi Samarii w przejęciu kontroli nad kultem i administracją w Jerozolimie. Zaakceptowanie małżeństwa kapłańskiego syna z Jerozolimy z córką Sanballata byłoby bez wątpienia dopuszczeniem obcych sił do władzy nad stolicą Judy. Wskazuje na to tekst Ne 13,30, gdzie osoba namiestnika jest wyraźnie określana jako někar („obcy”) ${ }^{15}$.

W kontekście tych zawirowań polityczno-religijnych autor Księgi Jonasza chce ukazać prawdziwy sens wybrania narodu wybranego przez Jahwe. Izrael ma być narzędziem w Bożych rękach, które powinno służyć wszystkim do zbawienia. Znajomość Bożego Objawienia i Prawa ma stać się dzięki Izraelitom dziedzictwem wszystkich. Wśród tradycji literackich ST tego typu przesłanie nie jest niczym nowym. Echo podobnych prawd możemy znaleźć już w Księdze Rodzaju podczas powołania Abrahama, kiedy staje się on „Ojcem mnóstwa narodów" (Rdz 17,4). W ten sam kontekst wpisuje się słowo proroka Amosa: „Czyż nie jesteście dla Mnie jak Kuszyci wy, synowie Izraela? - wyrocznia Pana. Czyż Izraela nie wyprowadziłem z ziemi egipskiej jak Filistynów z Kaftor, a z Kir - Aramejczyków?" (Am 9,7). Jeszcze mocniej podkreślają tę prawdę prorocy Proto- jak i Deutero-Izajasz. Począwszy od stwierdzenia w Iz 2,2-3: „Stanie się na końcu czasów, że góra świątyni Pańskiej stanie mocno na wierzchu gór i wystrzeli ponad pagórki. Wszystkie narody do niej popłyną, mnogie ludy pójdą i rzekną: «Chodźcie, wstąpmy na Górę Pana do świątyni Boga Jakuba! Niech nas nauczy dróg swoich, byśmy kroczyli Jego ścieżkami. Bo Prawo wyjdzie z Syjonu i słowo Pańskie - z Jeruzalem»”, poprzez motywy „najdalszych wysp” w Iz 42,4, aż do postaci „Sługi Jahwe”, który ma być „Znakiem dla wszystkich narodów” (Iz 42,6), i określenia Cyrusa „Pomazańcem Pańskim” (Iz 45,1) ${ }^{16}$.

Podsumowując nasze rozważania na temat pozytywnego obrazu pogan w Księdze Jonasza, warto poświęcić jeszcze kilka słów głównemu bohatero-

15 Por. J. Warzecha, Samarytanie - perspektywa polityczna i religijna, w: W. Chrostowski, Słowo Twoje jest Prawdą. Księga Pamiątkowa dla Księdza Profesora Stanisława Mędali w 65. rocznice urodzin, Warszawa 2000, s. 341.

16 Por. U. Struppe, dz. cyt., s. 79. 
wi - prorokowi Jonaszowi. Musimy pamiętać, że nigdzie w całej Księdze nie jest on charakteryzowany jako Żyd, choć przyznaje się do swojego hebrajskiego pochodzenia (Jon 1,9). W swoim proteście skierowanym ku Bogu nie występuje on z oskarżeniem przeciwko pogańskiemu miastu Niniwie. Na jego obronę przemawia również to, że w żadnej ze swoich wypowiedzi nie pragnie zarezerwować Boga-Jahwe tylko dla siebie lub dla narodu wybranego. W tekście nie ma także żadnego przykładu nienawiści wobec obcych i ich wierzeń religijnych.

Księga Jonasza jest zatem teologicznym opowiadaniem, które swoich czytelników, wszystkich wyznań i poglądów, zaprasza, aby razem z prorokiem walczyć o Bożą prawdę, która wypływa z ostatnich słów dzieła: Jahwe - Stwórca jest Bogiem łaskawym. On daje prawo i wyznacza drogę nawrócenia, powstrzymuje wykonanie kary i okazuje swoje przebaczenie. Dzieje się tak, ponieważ właśnie on, Jahwe - Bóg Izraela, jest Bogiem bezgranicznej miłości dla wszystkich żyjących.

\section{Jona angesichts der Heiden}

\section{Zusammenfassung}

Das Buch Jona wird als Teil des Zwölf - Propheten - Buches überliefert, obwohl es sich von den anderen prophetischen Büchern grundlegend unterscheidet. Zunächst ist es nicht eine Sammlung von Prophetensprüchen. Es ist durchgängig eine Erzählung. Eine Besonderheit des Buches liegt darin, dass es zur Gänze unter Heiden, also Nicht-Israeliten spielt. Die Umkehr der Sünder und die Umkehr Gottes sind die Leitworte des ganzen Buches (Jon 1,9; 3,8-10). Das Werk will als theologische Lehrerzählung darauf aufmerksam machen, dass der Gott Israels als der Schöpfergott ein Gott der Gnade ist (Jon 4,2). Er will - anders als sein Prophet Jona - die Sünder zur Umkehr bewegen und wird dann als Gott der grenzenlose Liebe zur ganzen Schöpfung sich der angedrohten Strafe gereuen lassen. 